\title{
Ketentuan Hukum Perbandingan sistem Pengawasan Terhadap Anggota Lembaga Parlemen Dibeberapa negara
}

\author{
Patawari \& Isnanto Bidja 2 \\ IFakultas Hukum Universitas Indonesia Timur, \\ Email: patawari.mh@gmail.com \\ 2Fakultas Hukum Universitas Tompotika Luwuk Banggai, \\ Email: isnantobidja@yahoo.co.id
}

\begin{abstract}
ABSTRAK
Pelaksanaan tugas dan fungsinya anggota parlemen, diperlukan adanya ketentuan pengawasan terhada anggota pada lembaga parlemen, sehingga di dalam menjalankan fungsinya maka anggota DPR berkesesuaian antara perencanaan, tugas dan fungsinya, dan tujuan yang hendak dicapai. Maka tentunya pengawas tersebut adalah memiliki kompetensi yang cukup untuk memahami tugas dan fungsi anggota DPR (yang diawasi). Paling tidak, sebagai pengawas lebih memahami dari pada tugas dan fungsi anggota DPR, hal tersebut yang dimaksud dengan kompetensi. Sedangkan kompetensi dapat tercipta dari proses akademik, pengalaman dan suatu kewenangan yang diberikan. Anggota dalam lembaga Parlemen, merupakan orang orang yang direkrut oleh partai politik untuk menjadi anggota parlemen, melalui proses seleksi sosial (konstituen) yang dipilih melalui pemilihan umum, hingga terpilih dan diberikan tugas dan fungsinya dan bekerja secara kolektifitas dengan ketentuan, yang memegang kekuasaan dalam pementukan perundang undangan, melakukan pengawasan dan melaksanakan fungsi budgeting.
\end{abstract}

Kata Kunci: Perbandingan Hukum, Sistem Pengawasan, Lembaga Parlemen

\begin{abstract}
The implementation of the duties and functions of parliamentarians requires the provision of oversight to members of parliamentary institutions, so that in carrying out their functions the members of the House of Representatives agree between their planning, duties and functions, and the objectives to be achieved. Then of course these supervisors have sufficient competence to understand the duties and functions of DPR members (supervised). At the very least, as supervisors understand better than the duties and functions of DPR members, this is meant by competence. While competence can be created from the academic process, experience and a given authority. Members in the Parliamentary institution, are people who are recruited by political parties to become members of parliament, through a process of social selection (constituents) elected through general elections, to be elected and given their duties and functions and work collectively with the provisions, who hold power in the formation legislation, supervise and carry out the budgeting function.
\end{abstract}

Keywords: Legal Comparison, Supervision System, Parliamentary Institutions 


\section{PENDAHULUAN}

Sebagaimana hasil survei Indonesian Coruption Watch (ICW) yang disampaikan oleh Luky Djani (detiknews, 2005) dalam jumpa pers di Jakarta Selatan, pada Kamis (24/2/2005):

“DPR RI periode 2004-2009 dinilai tidak representatif, didominasi kekuatan status quo, dan 5 komisinya mayoritas beranggotakan pengusaha......dan Data ICW juga memperlihatkan adanya peningkatan jumlah pengusaha yang menjadi anggota DPR. Pada DPR periode 19992004 ada 33,6 persen pengusaha, sedangkan pada periode 2004-2009 ada 39,09 persen. Mereka ini kebanyakan berada di komisi-komisi yang membidangi masalah perekonomian, perdagangan, atau keuangan dan perbankan, seperti Komisi IV, V, VI, VII, dan XI.”

Berdasarkan survei yang ditemukan oleh Luky Djani bahwa perkembangan kelompok tertentu dalam DPR tidak mencerminkan adanya keterwakilan masyarakat secara meyeluruh. DPR hanya didominasi oleh kalangan tertentu.

Beberapa survei di atas menggambarkan banyaknya anggota legislatif yang tidak memperjuangkan kepentingan rakyat, namun hanya mementingkan kepentingan golongan dan partai politik. Partai politik menjadi kekuatan tersendiri tanpa adanya tanggung jawab perkaderan yang dilakukan kepada anggota partai politik untuk didistribusikan masuk dalam lembaga legislatif. Banyak produk undang undang yang tumpang tindih satu dengan yang lainnya. Bahkan sejumlah Undang Undang yang disahkan DPR belakangan ini selalu digugat masyarakat ke Mahkamah Konsitusi (MK). Banyak orang menjadi anggota dewan karena menganggap pekerjaan tersebut bergelimang uang. Dalam konstek Indonesia DPR dinilai tidak maksimal dalam melaksanakan tugas dan fungsinya, karena rendahnya Pengawasan yang dilakukan oleh Badan Kehormatan atau diangkat dengan BK DPR RI. Sebagaimana Marulak Pardede bahwa:

"Badan Kehormatan (BK) dibentuk oleh DPR dan merupakan alat kelengkapan DPR yang bersifat tetap. Tata cara pelaksanaan tugas BK diatur dengan peraturan DPR tentang tata beracara BK (Imania, Saraswati, \& Asy'ari, 2016). Pembentukan BK di DPR merupakan respon atas sorotan publik terhadap kinerja sebagian anggota dewan yang buruk, misalnya dalam hal rendahnya tingkat kehadiran dan konflik kepentingan. BK DPR melakukan Penulisan dan pemeriksaan terhadap dugaan pelanggaran yang dilakukan oleh anggota DPR, dan pada akhirnya memberikan laporan akhir berupa rekomendasi kepada Pimpinan DPR sebagai bahan pertimbangan untuk menjatuhkan sanksi atau merehabilitasi nama baik anggota. Rapat-rapat Dewan Kehormatan bersifat tertutup. Tugas Dewan Kehormatan dianggap selesai setelah menyampaikan rekomendasi kepada Pimpinan DPR.” (BPHN, 2011)

Putusan BK DPR dinilai belum optimal mengarahkan anggota DPR bekerja sesuai dengan kode etik yang berlaku. Tidak hanya itu, inisiatif dan respons BK DPR terhadap pelanggaran kode etik yang dilakukan anggota DPR juga dianggap masih sangat rendah. Di sisi lain, minimnya efektivitas putusan BK atas perilaku anggota DPR tidak mampu memberikan 
sanksi yang optimal bagi pelanggaran kode etik. Sanksi yang diberikan belum mampu menimbulkan efek jerah.

Kondisi terakhir setiap partai yang ada di Badan Kehormatan DPR seperti telah tersandera. sepertinya saling menutupi dan saling bersandiwara ketika ada berbagai kasus-kasus yang melilit dan menghimpit yang terjadi pada partainya masing-masing. Saling melindungi bila terjadi keburukan pada masing-masing. Karenanya, keberadaan Badan Kehormatan DPR sudah tidak lagi efektif, harus ada kekuatan yang dapat mencairkan kondisi seperti ini. Oleh karena itu, ada usulan agar sebaiknya, anggota Badan Kehormatan tidak hanya anggota DPR, harus ada orang luar, seperti Akademisi, ahli hukum, harus ada tokoh masyarakat dan ahli pemilu.

Berdasarkan uraian di atas, terdapat beberapa fakta yang hendak dibahas dalam penulisan ini, yakni, kinerja Badan Kehormatan atau Majelis Dewan Kehormatan DPR cenderung tidak melakukan pengawasan yang efekif, aspiratif, berkualitas, dan baik dari segi kelembagaan, substansi perintah larangan dan kebolehan, dan bentuk pengawasan baik secara prefentif maupun secara represif terhadap DPR, berdasarkan pada peraturan yang telah ditentukan, sebagai upaya menciptakan anggota DPR yang aspiratif. Maka dari itu, melalui tulisan ini penulis melakuan pengkajia secara yuridis normatif dengan melakukan perbandingan di beberapa negaar terhadap ketentuan hukum pada pengawasan terhadap anggota Lembaga Parlemen di indonesia dengan beberapa negara di dunia

\section{PEMBAHASAN}

Sebagai dasar instrument pada sistem pengawasan terhadap anggota DPR, penulis mengacu pada pandangan Muchsan (2000) bahwa: Supaya pelaksanaan pengawasan dapat dijadikan sebagai suatu alat (instrumen) yang efektif maka perlu memperhatikan kriteria-kriteria sebagai berikut:

a. apa yang akan diawasi (obyek yang perlu diawasi).

b. mengapa perlu diadakan pengawasan.

c. dimana dan bilamana diadakan pengawasan dan oleh siapa pengawasan tersebut harus dilakukan.

d. bagaimana pengawasan tersebut dapat dilakukan.

e. pengawasan tersebut harus bersifat rasional, fleksibel, terus-menerus dan pragmatis.

Sebagai penjelasan terhadap sistem pengawasan terhadap anggota DPR guna mewujudkan anggota DPR yang aspiratif. Paling tidak ada 3 (tiga) sistem pokok untuk melakukan pengawasan terhadap anggota DPR yaitu; ketentuan lembaga pengawas, substansi yang diawasi, dan bentuk pengawasannya.

\section{A. Ketentuan Pengawasan Terhadap Anggota parlemen di beberapa negara.}

Ketentuan pengawasan terhadap anggota DPR adalah adanya lembaga atau peraturan untuk mengawasi anggota DPR dalam melaksanakan tugas dan fungsinya di parlemen. Sebagai 
perbandingan pengawasan terhadap anggota DPR dibeberapa negara, dan Indonesia sebagaimana diuraikan di bawah ini:

a) Analisis ketentuan pengawasan terhadap anggota parlemen dibeberapa negara

Sebagai perbandingan pengawasan terhadap anggota parlemen dibeberapa negara, berikut diuraikan Tabel VIII di bawah ini:

Tabel I

Ketentuan pengawasan terhadap anggota parlemen dibeberapa negara

\begin{tabular}{|c|c|c|}
\hline No. & Negara & $\begin{array}{l}\text { Ketentuan Pengawasan terhadap anggota Parlemen } \\
\text { dibeberapa Negara }\end{array}$ \\
\hline $\mathbf{1}$ & Inggris & $\begin{array}{l}\text { Lembaga: committee on standards in public life dengan } \\
\text { gabungan pihak eksternal dengan komite parlemen. }\end{array}$ \\
\hline 2 & Kanda & $\begin{array}{l}\text { Panduan: Prosedur parlemen } \\
\text { pernyataan: untuk standar perilaku dasar bagi anggota } \\
\text { parlemen }\end{array}$ \\
\hline 3 & Ethopia & Peraturan: untuk anggota parlemen \\
\hline 4 & Bahrain & $\begin{array}{l}\text { Ikhtisar: memberikan gambaran mengenai lembaga } \\
\text { parlemen }\end{array}$ \\
\hline 5 & Namibia & $\begin{array}{l}\text { Panduan mengembangkan sebagai acuan untuk anggota } \\
\text { parlemen }\end{array}$ \\
\hline 6 & Australia & $\begin{array}{l}\text { Panduan: mempunyai buku panduan sebagai prosedur } \\
\text { parlemen. }\end{array}$ \\
\hline 7 & India & $\begin{array}{l}\text { Panduan: mempunyai buku panduan sebagai prosedur } \\
\text { parlemen }\end{array}$ \\
\hline 8 & Iran & Lembaga Dewan Faqih (Dewan Konstitusi) \\
\hline 9 & Taiwan & $\begin{array}{l}\text { Peraturan: yaitu peraturan pengawasan etika anggota } \\
\text { parlemen dilakukan hanya oleh pihak eksternal. }\end{array}$ \\
\hline 10 & $\begin{array}{l}\text { Afrika } \\
\text { Selatan }\end{array}$ & $\begin{array}{l}\text { Lembaga: the Ethics Committee adalah lembaga Komite } \\
\text { Etik parlemen. }\end{array}$ \\
\hline 11 & Irlandia & $\begin{array}{l}\text { Pihak eksternal dengan komite parlemen: adalah } \\
\text { pelibatan pihak internal dan eksternal dalam mengontol } \\
\text { parlemen. }\end{array}$ \\
\hline
\end{tabular}

Berdasarkan pada table I di atas menggambarkan karakteristik dibeberapa negara, di dalam melakukan pengawasan terhadap anggota parlemen.

Pertama, kelembagaan. Bahwa adanya lembaga yang mengawasi sebagaimana pada negara Inggris yang disebut Committee on Standards Public Life. Keanggotaan pada komite tersebut adalah penggabungan baik pihak eksternal dan komite parlemen. Demikian halnya dengan negara Iran dengan adanya Lembaga Dewan Faqih (Dewan Konstitusi) yang bukan hanya mengawasi anggota Parlemen namun adalah juga mengawasi semua lembaga termasuk eksekutif dan yudikatif. Sedangkan Lembaga pengawas Negara Afrika Selatan disebut the Ethics Committee atau lembaga Komite Etik parlemen. Serta Negara Irlandia dengan adanya 
pelibatan komite parlemen baik pihak internal dan eksternal dalam melakukan kontrol (pengawasan) terhadap parlemen pada Negara Irlandia.

Kedua, Buku panduan. Terhadap beberapa negara sebagai upaya dalam melakukan pegawasan terhadap anggota Parlemen. Sebagaimana Negara Kanada, Bahrain, Australia, dan India dengan memiliki dan memberikan buku panduan kepada anggota parlemen untuk melaksanakan tugas dan fungsinya di parlemen. Sesungguhnya, hal tersebut sangat efektif sebab lembaga parlemen sebagai lembaga yang anggotanya tidak monoton (dilakuakan pergantian) sesuai dengan periode pada negara masing-masing. Tentunya, adanya anggota baru dan anggota lama sehingga perlu adanya buku panduan untuk menjadi dasar di dalam melaksanakan tugasnya.

Ketiga, peraturan. Adanya negara yang membuat peraturan khusus sebagai acuan dalam melakukan pengawasan terhadap anggota parlemen sebagaimana dengan Negara Ethopia, Taiwan. Pada Negara Taiwan ketentuan peraturan mengenai pengawasan anggota parlemen dilakukan dengan keanggotaan dari pihak eksternal parlemen.

Sebagaimana pada uraian diatas menggambarkan adanya beberapa perbedaan dan persamaan terhadap pihak atau lembaga untuk melakukan pengawasan terhadap anggota parlemen. Namun demikian, kesemuanya menghendaki adanya ketentuan untuk melakukan pengawasan terhadap anggota Parlemen di dalam menjalankan tugas dan fungsi masingmasing di parlemen. Baik ketentuan yang bersifat peraturan, pedoman, atau adanya lembaga pengawas.

Sedangkan, pengawas terhadap parlemen (DPR) di Negara Indonesia, sebagaimana diuraikan pada pembahasan selanjutnya di bawah ini.

b) Analisis ketentuan pengawas terhadap anggota Dewan Perwakilan Rakyat

Anggota DPR sebagai lembaga yang berperan dan berfungsi sebagai pengawas terhadap eksekutif, membuat legislasi, menerima aspirasi masyarakat, dan menetapkan budgeting (anggaran). Maka, tentunya diperlukan adanya kompetensi dan kemampuan anggota DPR yang dapat menjalankan tugas dan fungsi tersebut. Hal tersebut sehingga anggota DPR berdasarkan ketentuan agar aggita DPR dapat bekerja secara profesioal, aspiratif, dan akuntabilitas.

Guna mengukur kinerja anggota DPR maka diperlukan suatu lembaga, yang dapat melakukan pengawasan terhadap anggota DPR baik segi kehormatan, kinerja, maupun citra lembaga DPR. Sehingga, pasca reformasi dibentuk adanya lembaga pengawasan terhadap anggota DPR disebut dengan Badan Kehormatan (BK).

Sekaitan dengan eksistensi lembaga Badan Kehormatan DPR, diatur dalam Undang Undang Susduk dan Tata Tertib DPR. Pasal 98 UU No. 22 tahun 2003, ayat (2) point (g) mengatur bahwa alat kelengkapan DPR termasuk Badan Kehormatan. Selanjutnya ayat (5) Pasal yang sama disebutkan bahwa pembentukan, susunan, tugas dan wewenang alat kelengkapan sebagaimana dimaksud pada ayat (2) diatur dalam Peraturan Tata Tertib.

Lebih lanjut, terkait Tata Tertib, sebagaimana ketentuan Pasal 102 ayat (4) dimana point (f) dan (1) yang mengatur tentang substansi pengaturan di dalam Tata Tertib yang diantaranya 
melingkupi persoalan pengaduan dan tugas Badan Kehormatan serta kode etik dan alat kelengkapan lembaga.

Pada awalnya Badan Kehormatan, merupakan salah satu alat kelengkapan DPR guna melaksanakan pengawasan terhadap kinerja dan pengawasan etis anggota DPR, BK merupakan lembaga yang tidak tetap namun hanya melakukan bila terdapat kasus dan disepakati untuk menuntaskan suatu kasus yang menimpa anggota DPR. Namun, pada Periode 2004-2009, Badan Kehormatan didesain sebagai alat kelengkapan yang bersifat tetap, artinya Badan Kehormatan merupakan suatu keharusan untuk segera dibentuk diseluruh parlemen di Indonesia.

Ketentuan Badan Kehormatan DPR diatur dalam Tata Tertib DPR yang mengatur bahwa: alat kelengkapan DPR termasuk Badan Kehormatan. Sedangkan terkait dengan "pembentukan, susunan, tugas dan wewenang alat kelengkapan diatur dalam Peraturan Tata Tertib. Lebih lanjut terkait Tata Tertib, kemudian diatur pada Pasal 102 Ayat (4) point (f) dan (1) yang mengatur tentang substansi pengaturan di dalam Tata Tertib yang diantaranya melingkupi persoalan pengaduan dan tugas Badan Kehormatan serta kode etik dan alat kelengkapan lembaga.

Kewenangan pengawasan angota DPR perlu diperbesar, bahwa di dalam mengawasi adanya dugaan penyimpangan etik yang dilajukan oleh anggota DPR pengawasannya tidak hanya bersifat pasif, tetapi bersifat proaktif. Selama ini, BK baru bertindak setelah menerima pengaduan dari masyarakat dan pimpinan DPR maupun DPRD. Selain pasif, dengan posisi dan peran seperti itu membuat BK tidak responsive. Sementara banyak kasus-kasus yang terjadi pada DPR publik mengetahui dengan sangat jelas.

Sebagaimana pandangan Ucok Sky Khadafi (Koordinator Investigasi dan Advokasi Forum Indonesia untuk Transparansi Anggaran disingkat FITRA). Melalui hukumonline pada Kamis 17 Juli 2013 bahwa;

"Alangkah baiknya jika BK ditempati oleh pihak-pihak independen yang memiliki kewenangan untuk mengawasi DPR sehingga masyarakat dapat mengetahui bagaimana kinerja DPR sebenarnya," (Khadafi, 2012)

DPR sebaiknya diawasi oleh tim independen. Tujuannya, agar kinerja DPR dapat dinilai oleh pihak yang tidak berhubungan langsung dengan DPR, dan pihak pengawas tersebut adalah kepentingannya menegakkan peraturan, untuk kepentingan aspirasi masyarakat. Memang, DPR saat ini memiliki Badan Kehormatan (BK) yang berfungsi sebagai pengawas etika DPR, namun tidak mampu memberikan sanksi terhadap anggota DPR sesuai dengan perbuatannya. Di beberapa negara, model pengawasan yang dilakukan terhadap anggota parlemen adalah dilakukan dengan tiga model, yakni: Pertama, negara Taiwan sepenuhnya peraturan pengawasan etika anggota parlemen dilakukan hanya oleh pihak eksternal. Dengan melibatkan badan yudisial atau kuasi-yudisial yang mengawasi dan memberlakukan peraturan tentang anggota parlemen. Kekurangan model ini yang dirasakan banyak parlemen adalah bahwa hal itu membuat setiap pelanggaran peraturan harus melalui proses pidana dan karena itu dapat bersinggungan dengan ketentuan aturan yang berkaitan dengan kekebalan parlemen. Kelemahan lain dari pada model ini adalah karena akan berbenturan dengan kekuatan anggota parlemen sebagai pemengang kuasa regulasi. 
Kedua, mengandalkan sepenuhnya peraturan dalam legislatif itu sendiri, seperti yang dilakukan di Amerika Serikat. Juga sebagaimana Di Afrika Selatan yakni the Ethics Committee dapat melakukan penyidikan sendiri terhadap anggota parlemen.

Model ini bergantung pada pengaturan dari internal parlemen. Sistem ini membutuhkan pembentukan komite etik khusus, yang berkaitan dengan investigasi, pelaporan dan sanksi anggota parlemen yang diduga telah melanggar aturan.

Ketiga, menggabungkan pihak eksternal dengan komite parlemen melakukan pengawasan dan memberikan sanksi, sebagaimana Inggris dan Irlandia. Menggabungkan unsur-unsur dari dua yang pertama. Model ini melibatkan pembentukan sebuah regulator independen yang ditunjuk oleh dan bertanggung jawab kepada parlemen. Regulator kemudian bertanggung jawab untuk menyelidiki kasus dan memberikan pandangan pada anggota mengenai penerapan aturan, akan tetapi keputusan mengenai hukuman diputuskan oleh parlemen melalui sebuah panitia khusus yang sengaja dibentuk.

Sebagai perbandingan dengan beberapa negara, sebagaiamana pada pembahasan diatas bahwa sekaitan degan lembaga pengawas (Badan Kehormatan) idelanya adalah; 1) adanya lembaga yang di dalamnya adalah terdiri atas unsur dari luar anggota DPR. Sebagaimana dengan Negara Taiwan dan Negara Iran 2) perpaduan dengan pihak anggota DPR dan diluar anggota DPR. Sebagaimana pada Negara Inggris, Negara Irlandia.

Jika Negara Indonesia hendak menjaga Konstitusi (UUD NRI 1945) sebagaimana degan Negara Iran, maka bukan hanya pengawasan pada lembaga DPR, namun juga mengawasi baik Eksekutif maupun yudikatif, hal tersebut diatur dalam Konstitusi. Tujuannya adalah untuk menjaga nilai UUD NRI 1945 yakni; Ketuhana Yang Maha Esa, Kemanusiaan yan adil dan beradab, Persatuan Indonesia, Kerakyatan yang dipimpin oleh hikmat kebijaksanaan dalam permusyawaratan perwakilan, dan keadilan sosial bagi seluruh rakyat Indonesia. Atau sebagian kalangan disebut dengan Pancasila.

Sekaitan unsur yang dapat melakukan pengawasan atau mengisi lembaga pengawas adalah pihak yang berkesuaian dengan tugas dan fungsi anggota DPR adalah warganegara yang memiliki kemampuan dalam bidang hukum. Managemen (ekonomi), politik, dengen kredibiltas dan integritas yang teruji. Sebagai perbandingan bahwa Dewan Faqih pada Negara Iran salah satu indikatornya adalah mereka (warganegara) yang secara berturut-turut 40 tahun melaksanakan pendidikan.

Selain daripada adanya lembaga yang melakukan pengawasan, juga adanya panduan kepada anggota DPR di dalam menjalankan tugas dan fungsinya. Sehingga terhadap tugas pengawas dan anggota DPR yang diawasi masing-masing memiliki kesatuan visi dan kejelasan tugas dan fungsi masing-masing antara (DPR dan pengawas DPR).

\section{Ketentuan substansi pengawasan terhadap anggota Parlemen di beberapa negara}

Ketentuan mengenai substasi pengawasan terhadap anggota DPR adalah perihal atas kinerja anggota DPR untuk melaksanakan tugas dan fungsinya serta menjaga nama baik atau kehormatan lembaga DPR. Perlu adanya pengawas untuk melakukan pengawasan terhadap anggota DPR sehingga sebagai pengaturan wewenang pengawasan terhadap anggota DPR sebagaimana pandangan Musanef (1985) bahwa

"Harus ada kejelasan peraturan menyangkut Sasarannya, tertib susunannya, hubungan kerja antara satu dengan yang lainya, koordinasi dan komunikasi ke atas, ke samping, ke bawah 
dan ketentuan-ketentuan dan tata cara menyelenggarakannya atau secara singkat ditentukan" Rule of the games'nya."

Padangan tersebut menggambarkan bahwa pihak pengawas terhadap anggota DPR, bukan hanya dilakukan pada satu aspek kode etik saja namun demikian pengawasan harus bersifat meluas, bahkan termasuk dalam aspek kinerja hubungannya dengan lembaga lain yang juga harus diawasi.

Fenomena atas lembaga DPR Indonesia berdasarkan hasil penelitian Sebastian Salang Koordinator Forum Masyarakat Peduli Parlemen disingkat Formappi, pada Tahun 2012 memberikan penilaian dengan cara memanfaatkan data yang dikumpulkan dari sekretariat jenderal DPR dan partai-partai politik. Bahwa berdasarkan berdasarkan laporan yang rilis serangkaian mengenai hasil kerja DPR dengan indikator;

"kehadiran, persentase kunjungan ke daerah konstituen, dan tingkat transparansi pelaporan harta kekayaan, bahwa Para anggota dewan legislatif tidak terlalu piawai dalam menyelesaikan tugas-tugasnya. Dari sekitar 560 orang anggota DPR, hanya empat yang mendapatkan nilai "A" sementara mayoritas anggota-318 orang-dianggap gagal. Penilaian tersebut menunjukkan bahwa tak lebih dari sepertiga anggota menghadiri $85 \%$ sidang DPR. Para anggota yang jarang hadir-tingkat kehadiran kurang dari 40\%-mencakup 22\% dari seluruh anggota DPR.”

Sedangkan, berdasar regulasi DPR, para anggota yang absen dalam enam sidang berturutturut dapat dipecat. Wakil Ketua Badan Kehormatan DPR, Siswono Yudo Husodo, bahwa:

"Beberapa anggota melewatkan sidang empat hingga lima kali berturut-turut. Tapi, mereka muncul pada sidang berikutnya, Dengan begitu, sanksi tidak dapat dijatuhkan.”

Sekalipun diterapkan namun demikian sejumlah anggota DPR masih dapat menyiasatinya, sehingga tak satu pun anggota DPR yang pernah dipecat karena mangkir dari sidang. Selain dari pada itu beberapa masalah kinerja yang dilakukan oleh anggota DPR yang dilaporkan oleh Sebastian Salang yakni: pertama, di tahuan 2012 sekitar 70\% anggota DPR tidak menyambangi daerah pemilihan. Tiap Tahun DPR menangguhkan masa reses tiga bulan untuk melawat daerah konstituen. sekali dalam masa reses Tahunan DPR tidak memiliki kinerja memuaskan dalam urusan kunjungan ke daerah konstituen (Huda, 2005).

Kedua, DPR memiliki tugas meloloskan undang undang, mengawasi pemerintah, dan menandatangani proposal anggaran yang diajukan pemerintah. tak satu pun dari tugas-tugas tersebut yang dijalankan secara maksimal. Ketiga, Tiap Tahun, DPR memasang target meloloskan sejumlah UU. Pada beberapa Tahun belakangan, jumlahnya mencapai 66 hingga 93 UU. Namun, dalam empat Tahun terakhir, DPR hanya mampu memenuhi kurang dari setengah target menghasilkan UU setiap Tahunnya, Tahun 2012, DPR paling banyak meloloskan UU, yakni sekitar 30, Sementara di Tahun 2013, DPR hanya berhasil meloloskan 12 dari 75 target pembuatan UU. Oleh Karena lemanya pengawasan, maka berefek pada tidak berjalannya kinerja anggota DPR.

Hal tersebut menggambarkan bahwa kinerja anggota DPR memang diperlukan adanya pengawasan, sehigga dapat mewujudkan anggota DPR yang aspiratif.

Sebagai perbandingan, mengenai substansi pengawasan terhadap anggota Parlemen dibeberapa negara, sebagaimana diuraikan di bawah ini: 
a) Analisis substansi pengawasan terhadap anggota Parlemen dibeberapa negara.

Substansi pengawasan dimaksudkan adalah muatan yang hendak diawasi terhadap segala aktifitas anggota parlemen dibeberapa negara. Guna membandingkan substasi pengawasan terhadap parlemen dibeberapa negara, diuraikan pada Tabel IX di bawah ini:

\section{Tabel II}

Substansi pengawasan terhadap anggota parlemen dibeberapa negara

\begin{tabular}{|c|c|c|}
\hline No. & Negara & $\begin{array}{c}\text { Ketentuan Substansi Pengawasan terhadap } \\
\text { Parlemen di beberapa Negara }\end{array}$ \\
\hline $\mathbf{1}$ & Inggris & $\begin{array}{l}\text { - } \text { menetapkan kode etik } \\
\text { - Tidak mementingkan diri sendiri, } \\
\text { - Integritas, } \\
\text { - Obyektivitas } \\
\text { - } \text { Akuntabilitas. } \\
\text { - Keterbukaan atas semua keputusan. } \\
\text { - Kejujuran } \\
\text { - Kepemimpinan }\end{array}$ \\
\hline 2 & Kanada & $\begin{array}{l}\text { - Mengakui tugas mereka di parlemen. } \\
\text { - Menjaga kepercayaan publik. } \\
\text { - } \text { Menjaga integritas individu. } \\
\text { - } \text { Meyakinkan masyarakat. } \\
\text { - } \text { Buku panduan prosedur parlemen } \\
\text { - Panduan debat } \\
\text { - Panduan pertanyaan kepada menteri } \\
\text { - } \text { instrument undang-undang, } \\
\text { - } \text { urutan peraturan dan urutan program. } \\
\text { - } \quad \text { tidak memihak }\end{array}$ \\
\hline 3 & Uganda & $\begin{array}{l}\text { - prinsip dasarnya tidak; mementingkan diri } \\
\text { sendiri, integritas, obyektivitas, akuntabel, } \\
\text { keterbukaan, kejujuran dan mendorong tata } \\
\text { kelola pemerintahan yang baik. }\end{array}$ \\
\hline 4 & Ethopia & $\begin{array}{l}\text { - pelayan masyarakat. } \\
\text { - loyal } \\
\text { - jujur } \\
\text { - menjadi contoh bagi warga Ethiopia, } \\
\text { - menghormati masyarakat \& nasional } \\
\text { - menjaga martabat dan kehormatan parlemen” }\end{array}$ \\
\hline 5 & Australia & $\begin{array}{l}\text { - pengawasan yang menggunakan kantor publik } \\
\text { - pengawasan penggunaan dana publik; } \\
\text { - panduan prosedur parlemen yang lebih detail } \\
\text { - panduan lembaga berjalan. } \\
\text { - Panduan debat } \\
\text { - Panduan pertanyaan kepada menteri, } \\
\text { - aspek teknis mengenai instrument undang- } \\
\text { undang, urutan peraturan dan urutan program. }\end{array}$ \\
\hline
\end{tabular}


6 Bahrain - Menempatkan diri atas konflik kepentingan;

- Tidak menggunakan kantor untuk pribadi;

- Tidak Merendahkan martabat institusi

- Mempertaruhkan integritas;

- Tidak melemahkan integritas pemerintah.

7 Nabibia - melengkapi aturan prosedur

- menerangkan mengenai lembaga dan proses yang terjadi di dalamnya

8 India - Mempunyai panduan prosedur parlemen

- Termasuk panduan lembaga tersebut berjalan.

- Panduan debat.

9 Iran - Dewan Faqih (Majelis Pengawas Konstitusi)

- mengawasi jalannya pemerintahan,

- Mengawasi semua institusi yang berhubungan dengannya.

10 Taiwan - Pengawasan etika hanya oleh pihak eksternal.

- Melibatkan badan yudisial atau kuasi-yudisial

11 Afrika - Melakukan penyidikan sendiri terhadap Selatan anggota parlemen.

12 Irlandia - Melakukan pengawasan dan memberikan sanksi.

13 Chile - Menggunakan jabatan untuk keuntungan pribadi.

- Mendapatkan keuntungan untuk mempengaruhi tindakan pejabat.

- Menggunakan informasi pemerintah yang bersifat rahasia.

- Menerima hadiah dari pejabat atau pegawai melebihi nilai tertentu.

- Menerima honor dari pejabat publik.

- Mempunyai konflik kepentingan dalam hal keuangan.

- Melakukan nepotisme.

- Melakukan pekerjaan bisnis di luar parlemen dengan menggunakan jabatannya.

- Menerima pembayaran di luar sistem anggaran resmi.

Sebagaimana Table II di atas menggambarkan substansi pengawasan dibeberapa Negara, memiliki beberapa perbedaan dan persamaan mengenai substansi atau aspek yang diawasi tertuang dalam peraturan, dengan adanya buku panduan, sebagaimana diuraikan berikut di bawah ini:

Pertama, sebagaimana di Negara Inggris ketentuan substansi pengawasan terhadap anggota parlemen adalah menetapkan adanya kode etik baru yang komprehensif untuk anggota perleman materi kode etik paling tidak memuat bahwa 
1) Anggota parlemen tidak mementingkan diri sendiri, namun seharusnya bertindak untuk kepentingan masyarakat, tidak boleh memperoleh keuntungan financial atau keuntungan lain untuk diri mereka, keluarga, atau teman-teman mereka.

2) Integritas, dalam menjalankan pekerjaan publik, termasuk membuat penetapan, memberikan kontrak, atau merekomendasikan individu untuk penghargaan dan keuntungan, pemegang jabatan publik harus mempertimbangkan dasar kepantasan.

3) Obyektivitas, yaitu: menjalankan pekerjaan publik, termasuk membuat penetapan, memberikan kontrak, atau merekomendasikan individu untuk penghargaan dan keuntungan, pemegang jabatan publik harus mempertimbangkan dasar kepantasan.

4) Akuntabilitas, yaitu: pemegang jabatan publik bertanggung jawab atas keputusan dan tindakan mereka untuk masyarakat dan harus terbuka untuk tiap tindakan pengawasan yang ditujukan kepada mereka.

5) Keterbukaan, yaitu: pemegang jabatan publik harus terbuka atas keputusan dan tindakan yang mereka ambil. Mereka harus memberikan alasan untuk setiap keputusan mereka dan membatasi informasi hanya apabila ada kepentingan publik yang lebih luas.

6) Kejujuran, yaitu: pemegang jabatan publik mempunyai tugas untuk memberitahukan kepentingan pribadi terkait dengan tugas publik mereka dan mengambil langkahlangkah untuk menyelesaikan konflik kepentingan yang muncul untuk melindungi kepentingan publik.

7) Kepemimpinan, yaitu: pemegang jabatan publik harus mendorong dan mendukung prinsip-prinsip ini dengan kepemimpinan dan keteladanan melakukan pengawasan dan memberikan sanksi

Kedua, ketentuan substansi pengawasan terhadap anggota parlemen pada Negara Kanada secara umum mengakui bahwa tugas mereka di parlemen sebagai lembaga kepercayaan publik, dengan ketentuan: a) Menjaga kepercayaan publik dan menjaga integritas anggota parlemen secara individu dan penghormatan dan kepercayaan yang diberikan masyarakat kepada parlemen sebagai sebuah lembaga; b) Meyakinkan masyarakat bahwa semua anggota parlemen harus memegang standar yang menempatkan kepentingan publik diatas kepentingan pribadi anggota parlemen dan untuk memberikan sistem yang transparan sehingga masyarakat bisa menilai kebenarannya. Selain dari pada itu, Negara Kanada, mempunyai buku panduan prosedur parlemen yang lebih detail termasuk panduan mengenai; 1) bagaimana lembaga tersebut berjalan. 2) Panduan pendek debat meliputi aspekaspek seperti aturan debat dan bagaimana dan kapan dapat menyampaikan pertanyaan kepada menteri, 3) sejumlah aspek teknis mengenai instrument undang-undang, urutan peraturan dan urutan program. 4) Memberikan keyakinan yang lebih besar dan panduan bagi anggota parlemen dalam bagaimana menyesuaikan kepentingan pribadi mereka dengan tugas publik; 5) Memperkuat konsensus antara anggota parlemen dengan menetapkan aturan bersama dan menyediakan sarana dimana apabila ada pertanyaan seputar perilaku yang patut dapat dijawab oleh penasehat yang independen dan tidak memihak

Ketiga, Sedangkan Negara Uganda, memberikan karakteristik yang serupa, prinsip dasarnya adalah tidak mementingkan diri sendiri, integritas, obyektivitas, akuntabel, keterbukaan, kejujuran dan mendorong tata kelola pemerintahan yang baik.

Keempat, Negara Ethopia aturan yang berlaku adalah seorang anggota parlemen harus merupakan pelayan masyarakat yang loyal dan jujur dan menjadi contoh yang baik bagi warga Ethiopia, menjaga dan menghormati kepentingan masyarakat dan nasionale dan harus disetiap saat, menjaga martabat dan kehormatan parlemen. 
Kelima, Negara Australia parlemen yang menggunakan kantor publik untuk keuntungan pribadi, penggunaan dana publik sehingga melakukan pembahasan mengenai standar dan perilaku para politisi. Negara Australia mempunyai buku panduan prosedur parlemen yang lebih detail termasuk panduan mengenai bagaimana lembaga tersebut berjalan. panduan pendek meliputi aspek-aspek seperti aturan debat dan bagaimana dan kapan dapat menyampaikan pertanyaan kepada menteri, dan juga sejumlah aspek teknis mengenai instrument undang-undang, urutan peraturan dan urutan program.

Keenam, Negara Bahrain menempatkan diri mereka dalam posisi dimana mereka dapat mempunyai konflik kepentingan; a) Tidak mengindahkan berjalannya fungsi publik dan tugas resmi sebagaimana semestinya; b) Menggunakan kantor untuk keuntungan pribadi; c) Merendahkan martabat institusi atau jabatan; d) Mempertaruhkan integritas; e) Membahayakan atau melemahkan penghormatan atau kepercayaan terhadap integritas pemerintah

Ketujuh, Negara Nabibia melengkapi aturan prosedur dan menerangkan mengenai lembaga dan proses yang terjadi di dalamnya.

Kedelapan, Negara India mempunyai buku panduan prosedur parlemen yang lebih detail termasuk panduan mengenai bagaimana lembaga tersebut berjalan. panduan pendek meliputi aspek-aspek seperti aturan debat dan bagaimana dan kapan dapat menyampaikan pertanyaan kepada menteri, dan juga sejumlah aspek teknis mengenai instrument undangundang, urutan peraturan dan urutan program.

Kesembilan, Negara Iran adalah adanya Dewan Faqih (Majelis Pengawas Konstitusi) tidak hanya mengawasi jalannya pemerintahan, tetapi juga secara aktif mengawasi semua institusi yang berhubungan dengannya.

Sebagaimana pandangan Ehteshami (1995) bahwa tugas dan tanggung jawab Faqih (dewan pengawasa Konstitusi) sebagai berikut:

“(1) Supreme commander of the armed forces, (2) Determining the general policies of the IRI (in consultation with the Expediency Council), (3) Supervising the general implication of agreed policies, (4) Ordering referenda, (5) Power to declare war and peace and general troop mobilization, (6) Appointing and dismissing: (a) Members of the Council of Guardians, (b) Head of the judiciary, (c) Director of radio and television networks, (d) Chief of staff of the armed forces, (e) Commander-in-Chief of the IRGC, (f) Commander-in-Chief of the military and security forces, (7) Resolve differences and regulate relations among the three branches of the government, (8) Resolve, through the Expediency Council, problems which cannot be resolved by ordinary means, (9) Signing the decree naming the President after popular elections, (10) Impeaching the President for reasons of national interest pursuant to a verdict by the Supreme Court confirming his violation of his legal duties or a vote of no confidence by the Majlis." (Tanggung jawab Faqih adalah sebagai Komandan Agung angkatan bersenjata, (2) Menentukan kebijakan umum (konsultasi dengan Dewan Kebijaksanaan), (3) Melakukan pengawasan implikasi umum kebijakan yang disepakati, (4) Memesan referendum, (5) Power untuk menyatakan perang dan damai dan mobilisasi pasukan umum, (6) Penunjukan dan pemecatan: (a) Anggota Dewan Wali, (b) Kepala peradilan, (c) Direktur jaringan radio dan televisi, (d) Kepala staf angkatan bersenjata, (e) Komandan dan Kepala IRGC, (f) Komandan in Chief dari pasukan militer dan keamanan, (7) Menyelesaikan perbedaan dan mengatur hubungan antara tiga cabang pemerintahan, (8) menyelesaikan, melalui Kebijaksanaan Dewan, masalah yang tidak bisa diselesaikan dengan cara biasa, (9) Menandatangani 
Keputusan penamaan Presiden setelah pemilihan umum, (10) impeaching Presiden karena alasan kepentingan nasional sesuai dengan putusan oleh Mahkamah Agung mengkonfirmasikan pelanggarannya tugas hukumnya atau mosi tidak percaya oleh Majlis

Majelis pengawas konstitusiI Negara Republik Islam Iran menjalankan kekuasaan melalui empat jalur utama, yaitu: pertama, melalui kantornya sendiri; kedua, melalui perwakilannya disetiap propinsi; ketiga, melalui perwakilannya disetiap organisasi/lembaga nasional; dan keempat, sebagai Panglima Militer Tertinggi. Melalui kantornya Mahkamah Konstitusi dapat mengikuti perkembangan politik yang terjadi; melalui perwakilannya di Provinsi dia mendapatkan laporan tentang perkembangan politik di daerah. Bahkan ia memelihara pengaruh melalui perwakilan pada setiap organisasi/lembaga nasional.

Kesepuluh, Negara Taiwan sepenuhnya peraturan pengawasan etika anggota parlemen dilakukan hanya oleh pihak eksternal. Dengan melibatkan badan yudisial atau kuasi-yudisial yang mengawasi dan memberlakukan peraturan tentang anggota parlemen.

Kesebelas, Afrika Selatan melakukan penyidikan sendiri terhadap anggota parlemen. Keduabelas, Negara Irlandia melakukan pengawasan dan memberikan sanksi. Ketigabelas, Negara Chile

pengawasan hukum dalam bentuk kode etik anggota pada negara Chilie Putra, 2007) dimana materi kode misalnya berisi perbuatan perbuatan terlarang yang meliputi hal-hal sebagai berikut: a. menggunakan posisi publik untuk mendapatkan keuntungan pribadi. b. Mendapatkan keuntungan untuk mempengaruhi tindakan pejabat. c. Menggunakan informasi pemerintah yang bersifat rahasia. d. Menerima hadiah dari pejabat atau pegawai melebihi nilai tertentu. e. menerima honor dari pejabat publik. f. Mempunyai konflik kepentingan dalam hal keuangan. g. Melakukan nepotisme. h. Melakukan pekerjaan bisnis di luar parlemen dengan menggunakan jabatannya. i. Menerima pembayaran di luar sistem anggaran resmi.

Analisis di atas, terkait dengan substansi pengawasan terhadap parlemen dibeberapa negara, menunjukkan bahwa adanya ketentuan baik dalam peraturan maupun dalam bentuk kode etik sebagai pegangan oleh anggota parlemen didalam menjalankan tugasya. Sebagai poin penting substansi pengawasan terhadap anggota parlemen dibeberapa negara adalah adanya pengawasan terhadap kinerja, citra pribadi, dan citra lembaga parlemen terhadap anggota parlemen di dalam menjalankan tugasnya. Sehingga bekerja secara efektif dan sesuai dengan kehendak dan keinginan masyarakat yang berdasar pada ketentuan hukum yang berlaku dan atau kode etik parlemen.

b) Analisis substansi pengawasan terhadap anggota Dewan Perwakilan Rakyat

Badan Kehormatan merupakan lembaga pengawas terhadap anggota DPR. Substansi pengawasannya secara umum adalah sekaitan dengan kode etik anggota DPR, untuk menjaga pribadi anggota DPR, kehormatan Lembaga DPR. Adapun substansi yang dapat di awasi misalnya; kedisiplinan pada dalam menjalankan tugasnya, jarang menghadiri sidang atau rapat-rapat, tindakan yang merusak citra bangsa dan negara ataupun tindakan lainnya yang bermuara pada rusaknya lembaga DPR dimata publik.

Adanya beberapa kasus pelanggaran kode etik. Misalnya; pelesiran ke luar negeri tanpa hasil yang jelas, "calo" anggaran, serta ketidak patuhan dalam pelaporan harta kekayaan pejabat negara, tidak ada pengawasan terhadap anggota DPR disaat reses, Demikian pula amplop yang kerap beredar ditengah pembahasan rancangan undang-undang di DPR. 
Perlu adanya pengawas untuk melakukan pengawasan terhadap anggota DPR sehingga sebagai pengaturan wewenang pengawasan terhadap anggota DPR sebagaimana menurut Musanef (1995). Harus ada kejelasan peraturan menyangkut

"Sasarannya, tertib susunannya, hubungan kerja antara satu dengan yang lainya, koordinasi dan komunikasi ke atas, ke samping, ke bawah dan ketentuan-ketentuan dan tata cara menyelenggarakannya atau secara singkat ditentukan "Rule of the games'nya."

Padangan tersebut menggambarkan bahwa pihak pengawas terhadap anggota DPR, bukan hanya dilakukan pada satu aspek kode etik saja namun demikian pengawasan harus bersifat meluas, bahkan termasuk dalam aspek kinerja hubungannya dengan lembaga lain yang juga harus diawasi. Sebagai bentuk pengawasan yang dilakukan oleh BK terhadap anggota DPR karena adanya anggota dewan setelah terpilih menjadi anggota legislatif, bekerja diluar kewenangannya dan tanpa ada lembaga yang melakukan pengawasan.

Sekalipun anggota BK dapat melakukan pemberhentian terhadap anggota DPR, namun demikian peraturan tersebut (tata tertib) dibuat sendiri oleh anggota DPR, sebagaimana Undang Undang Tentang Susunan Dan Kedudukan Majelis Permusyawaratan Rakyat, Dewan Perwakilan Rakyat, Dewan Perwakilan Daerah, Dan Dewan Perwakilan Rakyat Daerah, Ayat:

(1) MPR, DPR, DPD, DPRD Provinsi, dan DPRD Kabupaten/Kota wajib menyusun kode etik yang berisi norma-norma yang harus dipatuhi oleh setiap anggota selama menjalankan tugasnya untuk menjaga martabat, kehormatan, citra, dan kredibilitas MPR, DPR, DPD, DPRD Provinsi, dan DPRD Kabupaten/Kota.

(2) Kode etik MPR, DPR, DPD, DPRD Provinsi, dan DPRD Kabupaten/Kota juga memuat jenis sanksi dan mekanisme penegakan kode etik yang ditetapkan oleh masing-masing lembaga.

Terhadap permasalahan di atas, maka sangat perlu melakukan pengawasan terhadap anggota DPR, kiranya dapat melaksanakan tugas aspirasi sebagai anggota DPR, pengawasan dengan maksud:

1. Adanya korelasi antara kehendak dan keinginan masyarakat, konstitusi, dan tugas dan wewenang anggota DPR secara efektif dan efisien untuk mewujudkan masyarakat adil dan makmur.

2. Adanya pengawasan terhadap pelaksanan tugas-tugas dan sikap pengabdian kepada masyarakat, bangsa, dan negara, serta sikap melayani dan mengayomi masyarakat.

3. Adanya pengawasan atas kinerja yag bermuara pada berdasarkan aspirasi masyarakat dalam aspek pembangunan. Yang diseleksi secara baik dan benar berdasarkan prinsip prinsip negara hukum.

4. Masyarakat diberikan ruang untuk menyampaikan aspirasinya secara baik, benar, di dalam memberikan informasi terhadap pihak pengawas.

5. Analisis, verifikasi terhadap penyampaian terhadap pengawas diseleksi secara benar dan tidak menimbulkan adanya informasi yang tidak dapat dipertanggungjawabkan.

6. Dengan adanya pengawasan maka membantu anggota DPR mengatasi berbagai masalah ditengah-tengah masyarakat.

7. Mengetahui adanya perbuatan menyimpan anggota DPR dari nilai, norma, yang berlaku di masyarakat.

Maka dengan demikian secara rinci substasni pengawasan badan Kehormatan terhadap anggota DPR ling tidak diantaranya; a. Adanya Pengawasan terhadap kinerja dalam hal tugas anggota DPR yang melanggar nilai konstitusi dan ideologi negara. b. adanya perbuatan dari 
pada anggota DPR yang melanggara Undang undang, dan peraturan yang mengaturnya. c. adanya pelanggaran anggota DPR yang melanggar nilai-nilai terhadap kepentingan masyarakat. d. adanya pelanggaran kode etik. e. Adanya pelanggaran terhadap asas dalam pelaksanaan pemerintahan $\mathrm{f}$. Adanya pelanggaran angota DPR sebagai peraturan yang dibuat oleh pengawas. g. adanya pelanggaran yang dilakukan oleh DPR atas cara dalam menjalankan tugas dan fungsinya sebagai angota DPR.

Menurut hemat penulis bahwa pengawasan adalah proses mengawasi segala tindakan terhadap suatu perencanaan pekerjaan/program yang telah ditentukan tujuannya dan kegunaannya. Dengan demikian bahwa batasan dari suatu pengawasan adalah sebagai berikut;

a. Adanya pihak pengawas dan diawasi;

b. Suatu pekerjaan berkesesuaian dengan tujuan dan kegunaannya (Aspiratif);

c. Sesuai dengan standar nilai yang di tentukan (hukum);

d. pengawasan berdasar pada suatu aturan yang jelas;

e. mengikuti perkembangan dan evaluasi (politik).

Substansi pengawasan paling tidak adalah adanya ketentuan hukum mengenai kewenangan badan pengawas untuk melakukan penentuan pengawasan terhadap anggota DPR yang dilakukan secara madiri dan tidak bertentangan dengan peraturan perundang undangan. Dan ketentuan peraturan perundang undangan yang mengatur kewenangan lembaga pengawas tujuannya adalah untuk mengatur kinerja dan segala bentuk kode etik anggota DPR dalam melaksanakan tugas dan kewenangan selama di DPR.

3 Bentuk Pengawasan Terahadap Parlemen di beberapa negara.

Bentuk pengawasan dapat saja dilakukan Sebagaimana pandangan Viktor M. Situmorang dan Jusuf Juhir (1998) bahwa Pengawasan dapat dibedakan menjadi: "Pengawasan yang dilakukan secara pribadi oleh pimpinan atau pengawas dengan mengamati, meneliti, memeriksa, mengecek sendiri "on the spot" ditempat pekerjaan dan menerima laporan-laporan secara langsung pula dari pelaksana. Hal ini dilakukan dengan inspeksi. Tujuan pada pengawasan sebagaimana pandangan tersebut adalah muaranya pada pengawasan preventif yaitu adanya upaya mencegah atas adanya kesalahan dan mencoba meluruskannya sesuai dengan nilai konstitusi, dan juga dapat tujuan pengawasan represif guna mencegal atau tidak memberikan ruang untuk diberlakukan atau dilaksanakan karena nyata adanya pertentangan dengan konstitusi.

Badan Kehormatan sebagai lembaga pengawas, diberikan kewenangan untuk dapat memecat atau me-recall anggota DPR namun demikian Badan Kehormatan tidak optimal melaksanakan tugasnya. Penegakan kode etik yang oleh BK, belum dapat menimbulkan efek jera bagi anggota DPR Rauf,, Bunga \& Djanggih, 2018). Tebang Pilih, Inisiatif rendah, Kemampuan penyelidikan rendah, tertutup, Penerapan sanksi ringan, sedang dan berat (tidak ada ketentuan dalam tatib), Alasan penerapan sanksi tidak transparan, Sanksi Ringan, Tidak memberikan rehabilitasi, Tidak ada koordinasi dengan instansi terkait (BPK, BPKP, KPK, Pemda dan instansi terkait lainnya), Belum memiliki aturan tentang konflik kepentingan dalam pemrosesan kasus.

Jika, BK sebagai lembaga pengawas terhadap anggota DPR, seharusnya BK diberikan kewenang untuk menyusun kode etika yang memuat norma, nilai yang berdasar pada konstitusi dan aturan yang berlaku sebagai dasar hukum. Bukan justru anggota DPR yang 
hendak diawasi namun dia (Anggota DPR) sendiri sebagai pembuat peraturan. Demikian juga pada bentuk sanksi yang diberikan, kesemuanya diatur dalam suatu peraturan yang diberikan kewenangan oleh BK sebagai lembaga pengawas untuk menentukan segala peraturan yang terkait dengan pengawasan yang dilakukan oleh anggota DPR.

Kewenangan bentuk pengawasan terhadap angota DPR perlu diperbesar, bahwa di dalam mengawasi adanya dugaan penyimpangan etik yang dilajukan oleh anggota DPR pengawasannya tidak hanya bersifat pasif, tetapi bersifat proaktif. Selama ini, BK baru bertindak setelah menerima pengaduan dari masyarakat dan pimpinan DPR maupun DPRD. Selain pasif, dengan posisi dan peran seperti itu membuat BK tidak responsive. Sementara banyak kasus-kasus yang terjadi pada DPR publik mengetahui dengan sangat jelas.

a) Analisis bentuk pengawasan terhadap Parlemen dibeberapa negara

Bahwa kode etik dapat saja memberikan efek (sanksi) kepada anggota parlemen jika ditemukan adanya melanggaran, dan dilakukan oleh lembaga kode etik tersebut. Sebagaimana pada Tabel III di bawah ini:

Tabel III : Bentuk Pengawasan terhadap parlemen di beberapa Negara

\begin{tabular}{|c|c|c|}
\hline No. & Negara & Bentuk pengawasan \\
\hline 1 & $\begin{array}{l}\text { Sierra } \\
\text { leone }\end{array}$ & Sanksi disiplin \\
\hline 2 & Perancis & $\begin{array}{l}\text { Sanksi teguran, teguran dengan catatan, } \\
\text { mencabut hak bicara, (mengusir dari ruangan) }\end{array}$ \\
\hline 3 & Prancis & Lerangan pencalonan kembali untuk satu tahun. \\
\hline 4 & Amerika & Pemotongan gaji \\
\hline 5 & Irlandia & Denda atau kecaman publik \\
\hline 6 & Jerman & $\begin{array}{l}\text { Parlemen mengumumkan pelanggaran kepada } \\
\text { para pemilih, denda atau pemotongan gaji, } \\
\text { permintaan maaf kepada parlemen, pengusiran, } \\
\text { pemotongan gaji untuk satu periode, } \\
\text { diumumkan dipublik, mencabut hak bicara }\end{array}$ \\
\hline
\end{tabular}

Sebagaimana Tabel III mengenai pengawasan secara prefentif dan represif pada parlemen dibeberapa Negara, sebagaimana diuraikan pada di bawah ini:

Pertama, Negara Sierra Leone memberikan kewenangan kepada Ketua Parlemen untuk merujuk Anggota yang telah mencemarkan nama baik seseorang, sedangkan menentukan sanksi disiplin merupakan domain dari the Committee of Privileges. Kedua, Negara Perancis sanksi yang diberikan oleh Ketua Parlemen atau Komite Etika umumnya tiga kategori; sanksi teguran, teguran dengan catatan, dan mencabut hak bicara anggota (mengusir dari ruangan). Perancis hanya ada satu pilihan, pelarangan pencalonan kembali untuk satu tahun.

Ketiga, Di Senat Amerika Serikat, ini dapat disertai dengan pemotongan gaji sejak senator tersebut diusir. Keempat, Irlandia melibatkan Suspensi, denda atau kecaman publik. Kelima, Jerman Ketua Parlemen mengumumkan pelanggaran kepada para pemilih dan membiarkan mereka menentukan nasib anggota parlemen tersebut. Beberapa bentuk sanksi dapat diberlakukan di dalam kode etik anggota DPR adalah 1) denda atau kehilangan gaji (pemotongan gaji), 2). permintaan maaf kepada parlemen, 3) pengusiran; 4) pemotongan gaji untuk satu periode. 5) diumumkan di publik 6) pelarangan pencalonan kembali 7) sanksi 
teguran, 8) teguran dengan catatan, 9) mencabut hak bicara anggota (mengusir dari ruangan) (Prima, 2019).

Disisi lain, Fungsi -fungsi partai politik sebagaimana yang dilakukan di Negara Jepang dan negara Chile merupakan cara efektif dan ideal terhadap suatu partai politik dengan berusaha untuk mengawasi anggota partai poltiknya yang duduk di parlemen untuk tujuan pengembangan karirnya. Sebagaimana pandangan Carl J.Friedrich mengungkapkan bahwa:

"A Political, party is a group of human beings, stably organized with the objective of securing or maintaining for its leader the control of a govermant, with the further obyektive of giving to members of the party, though such control ideal and material benefits and advantages.'”'

Partai politik adalah sekelompok manusia yang terorganisir secara stabil dengan tujuan merebut atau mempertahankan penguasaan terhadap pemerintahan bagi pimpinan partainya kemanfaatan yang bersifat ideal serta material.

Namun demikian pengwasan politik tidak berada pada pengawasan yang secara struktur sebagai pengawas anggota DPR, partai politik idealnya adalah tidak menjadi pengawas terhadap anggota DPR, namun ia hanya melaksanakan fungsi-fungsi partai politik diluar parlemen. Yang menjadi pengawas sosial anggota DPR adalah mereka sebagai warganegara yang memiliki kompetensi, independen profesional, dan memiliki pemahamam atau kompetensi atas kinerja dan yang ada kaitannya dengan tugas pokok dan fungsi anggota DPR.

Etika politik membantu untuk menganalisis korelasi antara tindakan individual, tindakan kolektif, dan struktur-struktur politik yang ada. Penekanan adanya korelasi ini menghindarkan pemahaman etika politik yang diredusir menjadi hanya sekadar etika individual perilaku individu dalam bernegara. Di dalam etika politik moral akan membantu mempertajam makna tanggung jawab, dan memungkinkan untuk mengorganisir tanggung jawab. Etika Politik tidak identik dengan demokrasi, namun demokrasi sebagai sistem politik lebih memberi peluang bagi penyelesaian konflik secara damai (Noviati, 2016). Tujuan etika politik sendiri adalah mengarahkan kehidupan politik yang lebih baik, baik bersama dan untuk orang lain, dalam rangka membangun institusi-institusi politik yang adil (Imawam, 2001).

Namun demikian, partai politik merupakan suatu organisasi yang memiliki anggaran dasar dan anggaran rumah tangga atau bentuk peraturan lainnya, dan mengikat anggota partai politik. seharusnya, anggaran dasar, anggaran rumah tangga dan peraturan lainnya adalah tidak bertentangan dengan aturan perundang undangan. Sebab sekalipun mampunyai cita ideal dalam aturan partai politik tetapi tidak berkorelasi atau tidak berdasar pada suatu konstitusi, maka tentunya akan tidak dapat mewujudkan cita negara. sebab antara satu konstitusi berkehendak lain, sedangkan partai politik juga berkehendak lain (tidak berdasar pada peraturan). Perbedaan tersebut harusnya tidak terjadi.

Dari pandangan tersebut di atas, pengawasan politik anggota DPR penulis tidak memaksudkan pengawasan yang dilakukan oleh partai politik, sebab partai politik bukan pengawasan yang dilakukan dalam sistem lembaga ketatanegaraan Indonesia. Partai politik melakukan pengawasan pada anggotanya untuk karirnya saja, sebagaimana yang terjadi pada Negara Jepang dan Negara Chile.

Pengawasan politik adalah, sekaitan dengan tindakan anggota DPR di dalam menjalankan tugas dan fungsinya, serta kebijakan-kebijakan, yang sesuai atau tidak sesuai dengan ketentuan hukum. pengawasan politik juga di maksudkan pada pengawasan terhadap kinerja 
anggota DPR yang dapat dilihat dari administrasi kesekertarian DPR, hal tersebut dimaksudkan pengawas menjadikan alat bukti atas kinerja yang dilakukan oleh anggota DPR (Golap, 2017).

b) Analisis bentuk pengawasan terhadap anggota Dewan Perwakilan Rakyat.

Dengan adanya suatu pengawasan terhadap anggota DPR maka hal tersebut dimaksudkan sebagai bentuk pengawasan yang dilakukan secara vertikal untuk memberikan interpretasi dengan mengacu pada sebuah aturan, dan sesuai dengan kewenang yang diberikan kepada badan pengawas.

Anggota Pengawas adalah adanya orang berkompeten memberikan tafsiran untuk memberikan suatu nilai akhir, setiap nilai akhir tersebut akan bekonseskuensi pada ditangguhkan atau dibatalkan pada suatu pekerjaan yang hendak dilaksanakan, dan berkonsekuensi baik secara administrasi maupun secara politik sampai pada konsekuensi secara sosial terhadap orang yang diawasi. Artinya bahwa setiap pengawasan harus memiliki kekuatan hukum (wewenang) untuk menjatuhkan sanksi. Baik secara preventif, repsesif dan itulah kekuatan dari pada pengawasan itu sendiri.

Sekalipun pengawasan dilakukan oleh orang, dapat saja dibantu dengan berbagai alat di dalam melakukan pengawasan baik secara elektronik, secara administrasi maupun berdasarkan laporan informasi pandangan pemberi mandat (masyarakat). Alat tersebut hanya menjadi suatu alat ukur dan menjadi alat bukti terhadap suatu tindakan yang dilakukan oleh seseorang (anggota DPR) yang diawasi. Sehingga dengan adanya alat tersebut akan menjadi dasar untuk memberikan suatu tindakan pengawasan represif dengan sanksi sesuai dengan bobot perbuatan seorang yang diawasi.

Untuk ukuran antara pengawas yang diawasi, pembeda pengawas dan yang diawasi, sampai pada bentuk pengawasannya, sebagaimana pandangan Viktor M. Situmorang dan Jusuf Juhir (1998) bahwa Pengawasan dapat dibedakan menjadi:

1. Pengawasan Langsung dan tidak langsung. Pengawasan yang dilakukan secara pribadi oleh pimpinan atau pengawas dengan mengamati, meneliti, memeriksa, mengecek sendiri "on the spot" ditempat pekerjaan dan menerima laporan-laporan secara langsung pula dari pelaksana. Hal ini dilakukan dengan inspeksi (Situmorang \& Juhir, 1998)

2. Pengawasan Preventif dan Represif Arti harafiah pengawasan "preventif" adalah pengawasan yang bersifat mencegah. Mencegah artinya menjaga jangan sampai suatu kegiatan itu terjerumus pada kesalahan.

Padangan tersebut tidak memberikan suatu batasan adanya pengawasan dari atasan terhadap bawahan, juga tidak memberikan batasan adanya pengawasan yang dilakukan dari bawah ke atas, dari samping kesampingnya, demikian juga tiada pengawasan secara diagonal (dari bawah ke samping atas).

Maka dengan demikian, pengawasan sesungguhnya tidak harus dibatasi dari segi atas bawah samping atau diagonal, sebab tergatung pada suatu ketentuan yang dipertimbangkan berdasakan suatu kompetensi dan kewenangan untuk melakukan suatu pengawasan. Jika, ketentuan menghendaki adanya pengawasan dari bawah terhadap atasan maka itu berarti tidak keliru sebab pengawasan harus berdasar pada peraturan menjadikan dasar siapa yang diawasi dan siapa yang mengawasi, dan caranya yang harus jelas dalam suatu peraturan. Jika 
suatu ketentuan dari bawah yang memiliki kewenangan, maka tentunya dari atas akan bersedia untuk diawasi. Sederhanya bahwa siapapun dapat memberikan suatu pengawasan.

Menurut hemat penulis bahwa pengawasan adalah proses mengawasi segala tindakan terhadap suatu perencanaan pekerjaan/program yang telah ditentukan tujuannya dan kegunaannya. Dengan demikian bahwa batasan dari suatu pengawasan adalah sebagai berikut;

a. Adanya pihak pengawas dan diawasi;

b. Suatu pekerjaan berkesesuaian dengan tujuan dan kegunaannya (Aspiratif);

c. Sesuai dengan standar nilai yang di tentukan (hukum);

d. pengawasan berdasar pada suatu aturan yang jelas;

e. mengikuti perkembangan dan evaluasi (politik).

Sedangkan tahapannya pengawasan adalah mulai dari adanya standar aturan, pelaksanaan suatu aturan disertai dengan sistem pendukung, target yang hendak dicapai atau tujuannya.

Pelaksanaan tugas dan fungsinya anggota DPR, diperlukan adanya ketentuan pengawasan, sehingga di dalam menjalakan fungsinya maka anggota DPR berkesesuaian antara perencanaan, tugas dan fungsinya, dan tujuan yang hendak dicapai. Maka tentunya pengawas tersebut adalah memiliki kompetensi yang cukup untuk memahami tugas dan fungsi anggota DPR (yang diawasi). Paling tidak bahwa sebagai pengawas lebih memahami dari pada tugas dan fungsi anggota DPR, hal tersebut yang dimaksud dengan kompetensi. Sedangkan kompetensi dapat tercipta dari proses akademik, pengalaman dan suatu kewenangan yang diberikan.

Terkait anggota DPR sebagai lembaga yang terdiri atas orang orang yang direkrut oleh partai politik untuk menjadi anggota DPR, melalui proses seleksi sosial (konstituen) yang dipilih melalui pemilihan umum, hingga terpilih dan diberikan tugas dan fungsinya dan bekerja secara kolektifitas dengan ketentuan (Kuswanto, 2017), yaitu; DPR sebagai lembaga yang memegang kekuasaan membentuk undang undang, secara bersama sama dengan Presiden untuk mendapatkan persetujuan. Sedangkan Anggota DPR memiliki fungsi legislasi, fungsi anggaran dan fungsi pengawasan, yang secara bersamaan memiliki juga hak interpelasi, hak angket, dan hak menyatakan pendapat, hak mengajukan pertanyaan, menyampaikan usul dan pendapat, serta hak imunitas.

Pengawasan terhadap anggota DPR adalah pengawasan baik atas kinerja maupun pengawasan terhadap sikap selama menjabat sebagai anggota DPR. sebagaimana cita di dalam konsideran "Mengingat" huruf a Undang-Undang Republik Indonesia Nomor 22 Tahun 2003 Tentang Susunan Dan Kedudukan Majelis Permusyawaratan Rakyat, Dewan Perwakilan Rakyat, Dewan Perwakilan Daerah, Dan Dewan Perwakilan Rakyat Daerah.

Bahwa untuk melaksanakan kedaulatan rakyat atas dasar kerakyatan yang dipimpin oleh hikmat kebijaksanaan dalam permusyawaratan/perwakilan perlu diwujudkan lembaga permusyawaratan rakyat, lembaga perwakilan rakyat, dan lembaga perwakilan daerah yang mampu mencerminkan nilai-nilai demokrasi serta dapat menyerap dan memperjuangkan aspirasi rakyat termasuk kepentingan daerah sesuai dengan tuntutan perkembangan kehidupan berbangsa dan bernegara;

Eksistensi lembaga DPR sebagai lembaga untuk melaksanakan kedaulatan rakyat. sedangkan nilai dari kedaulatan rakyat dan menjadi tanggungjawab dari pada anggota DPR adalah menyerap dan memperjuangkan aspirasi rakyat. Maka dari itu, di dalam melaksanakan 
kedaulatan rakyat untuk menyerap aspirasi rakyat, indikatornya adalah kinerja para anggota DPR. bahwa jika kinerja anggota DPR adalah aspiratif maka tentunya akan menjadi lembaga yang mencerminkan kedaulatan rakyat yan aspiratif pula (Arifin, 2019).

Pada dasarnya kinerja anggota DPR tidak begitu mudah, sebab akan bersentuhan langsung dengan kebutuhan masyarakat (konstituen), dan kepentingan orang banyak. Terhadap kinerja tugas dan fungsi yang diberikan maka harus berdasar pada konstitusi/UUD NRI 1945 dan ketentua hukum yang mengaturnya. Aspirasi masyarakat tidak an sich menjadi tolak ukur aspiratif tidaknya anggota DPR.

Sebagai dasar di dalam melakukan pengawasan terhadap anggota DPR guna mengukur kinerja anggota DPR bekerja secara aspiratif, yakni

1. Kinerja anggota DPR berkesesuaian dengan kehendak dan keinginan sebagai mandatir masyarakat (konstituen).

2. Kinerja anggota DPR adalah berdasarkan pada standa hukum yang mengaturnya.

3. Kinerja anggota DPR adalah berdasarkan pada tugas, fungsi dan kewenangan yang diamanatan (hukum).

Pengawasan aspek hukum terhadap anggota DPR adalah pengawasan atas tindakan terhadap anggota DPR yang dilakukan baik secara individu maupun secara bersama-sama yang diberikan sanksi sesuai dengan perbuatannya, baik pidanan, perdata maupun administrasi negara. Di dalam proses hukum yang berjalan maka pengawasan terhadap anggota DPR adalah diberikan wewenang untuk membantu pihak yang berwewenang baik kepolisian, Kejaksaan Agung, maupun pihak lainnya dalam hubungan perdata untuk memberikan keterangan dan bukti yang cukup atau mempertahankan anggota DPR sesuai dengan bukti bukti yang dimiliki. Hal tersebut dimaksudkan adalah kiranya anggota DPR yang diproses secara hukum tidak berlarut sehingga anggota DPR terjadi kekosongan kursi, yang seharunya lengkap untuk menjalankan berbagai tugas dan fungsinya sebagai wakil rakyat di parlemen (DPR).

Maka dengan demikian guna mewujudkan anggota DPR yang aspiratif, maka diperlukan adanya pengawasan baik preventif hingga represif yang sesuai dengan perbuatan yang dilakukan anggota DPR. Guna menjalankan berbagai bentuk pengawasan terhadap anggota DPR, maka pihak pengawas harus memahami dan mengatahui, profesionalisme atau berpengalaman baik secara akademik atau dalam dunia praktis untuk menjadi anggota pengawas anggota DPR. Sehingga, anggota DPR dapat terjaga dari sikap independensi dengan etika yang baik sebagai mandataris masyarakat.

Terhadap pengawas, walaupun dengan adanya Badan Kehormatan, namun berbagai hal yang harus ditata ulang untuk dapat melahirkan pengawas yang independen; yakni pengawas harus independen, bukan anggota DPR, bukan anggota partai politik, mereka adalah sebagai kalangan profesionalisme, independen, memahami persoalan kinerja anggota DPR, punya kompetensi dibidang hukum kompetensi dibidang politik (bukan partai politik), dan punya kompetensi dibidang managemen, punya kompetensi komunikasi massa, dan kompetensi sebagai pers.

Pengawasan terhadap anggota DPR, harusnya diberikan kewenangan untuk membuat tata tertib anggota DPR. Sebagai dasar aturan di dalam melaksankaan pengawasan, tata tertib terikut sanksi. Idealnya, tidak diberikan kepada angota DPR, sebab logikanya bahwa bagaimana bisa terawasi secara baik sedangkan peraturan (kode etik) dibuat sendiri oleh 
mereka yang diawasi. Terhadap beberapa bentuk pengawasan di atas maka kesemua itu harus dimasukkan di dalam peraturan perundang undangan kiranya menjadi payung hukum untuk dijalankan.

Jika mengacu pada sanksi terhadap anggota DPR yang melakukan pelanggaran atas ketentuan yang di tetapkan oleh pengawas adalah domain Badan Kehormatan untuk memberikan sanksi. Sebagai perbandingan untuk menjadi inspirasi bentuk sanksi di beberapa Negara hubungannya dengan saksi terhada anggota DPR, diantaranya:

1. Pemotongan gaji terhadap anggota DPR.

2. Denda dan kecaman kepada anggota DPR.

3. Mengumumkan pelanggaran kepada para pemilih dan membiarkan mereka menentukan nasib Anggota Parlemen tersebut.

4. Permintaan maaf kepada parlemen,

5. Pengusiran;

6. Pelarangan pencalonan kembali

7. Sanksi teguran,

8. Teguran dengan catatan,

9. Mencabut hak bicara anggota (mengusir dari ruangan).

\section{KESIMPULAN}

Ketentuan hukum materi muatan pengawasan terhadap anggota DPR belum memadai pada aspek keanggotaan lembaga pengawas, substansi sekaitan dengan perintah larangan, dan kebolehan, dan bentuk pengawasan baik prefentif maupun represif terhadap anggota DPR. Hal tersebut dipengaruhi anggota lembaga pengawas DPR didominasi oleh kalangan internal anggota DPR, yang notabene dipengaruhi kepentingan partai politik. Sehingga, dalam melaksanakan tugas, dan kewenangan sebagai aggota DPR belum aspiratif. materi perundang undangan terkait dengan pengawasan terhadap anggota DPR memuat adanya aspek kelembagaan yang melibatkan pihak luar anggota DPR, substansi yang memuat adanya perintah larangan, dan kebolehan terhadap anggota DPR, dan bentuk pengawasan baik secara prefentif maupun secara represif terhadap anggota DPR.

\section{DAFTAR PUSTAKA}

Arifin, M. Z. (2019). Suatu Pandangan Tentang Eksistensi Dan Penguatan Dewan Perwakilan Daerah. Jurnal Thengkyang, 1(1), 1-15.

BPHN, (2011). laporan akhir penelitian Hukum.tentang efektivitas Badan Kehormatan DPR/DPRD.

Ehteshami, A.( 1995). After Khomeini: The Iranian Second Republic. London: Routledge.

Golap, M. (2017). Eksistensi Fungsi Dewan Perwakilan Daerah (DPD) Dalam Sistem Ketatanegaraan Indonesia Menurut Undang-Undang Dasar Negara Republik Indonesia 1945. Jurnal Noken: Ilmu-Ilmu Sosial, 2(2), 50-67.

Huda, N. (2005). Otonomi Daerah Filosofi sejarah dan Perkembangan dan Problematika. Pustaka Pelajar. Yokyakarta. 
Imania, D., Saraswati, R., \& Asy'ari, H. (2016). Penegakan Kode Etik Anggota Dewan Perwakilan Rakyat melalui Mahkamah Kehormatan Dewan. Diponegoro Law Journal, 5(3), 1-16.

Imawan, R. (2001). Hubungan Antar Lembaga dan Pemerintah Sistem Politik dan Pemerintah Indonesia "Fungsi Perwakilan, Pembentukan Legitimasi dan Pengambilan Keputusan, Diktat Ilmiah. Program Magister Administrasi Publik Universitas Gadjah Mada. Yogyakarta.

Kuswanto, K. (2017). Politik Hukum Pengaturan Unsur Pimpinan Partai Politik. Perspektif Hukum, 16(2), 188-201.

Muchsan, (200o). Sistem Pengawasan Perbuatan Aparat Pemerintah dan Peradilan Tata Usaha Negara, Liberty. Yokyakarta.

Musanep. (1985). Sistem Pemerintahan di Indonesia. Gunung Agung. Jakarta.

Noviati, C. E. (2016). Demokrasi dan Sistem Pemerintahan. Jurnal Konstitusi, 1o(2), 333-354.

Prima, J. (2019). Perbandingan Kewenangan Badan Legislatif Di Indonesia Dan Amerika Serikat. Negara dan Keadilan, 8(1), 1-12

Putra, A.S. (2007). Naskah Kode Etik DPR RI dan Tata Beracara, Bahan Project Management Unit PROPER UNDP Bekerjasama dengan Sekretariat Jenderal DPR RI.

Rauf, M. A. A., Bunga, M., \& Djanggih, H. (2018). Hak Recall Partai Politik Terhadap Status Keanggotaan Dewan Perwakilan Rakyat dalam Sistem Ketatanegaraan Indonesia. Jurnal Magister Hukum Udayana (Udayana Master Law Journal), 7(4), 443-455.

Situmorang, V.M. \& Juhir, J. (1998). Aspek Hukum Pengawasan melekat Dalam Lingkungan Aparatur Pemerintah. Rineka Cipta, Jakarta Cetakan II .

\section{Internet}

Lucky Djani 2005. VIVAnews, (http://nasional.news.viva.co.id/news/ read/421170-knpibelum-tentukan-sikap-final-soal-bbm. Diakses 1 November 2013)

Luky Djani 2005. (http://news.detik.com/index.php/detik.read/tahun/2005 /bulan/o2/tgl/25/time/o04730/idnews/299311/idkanal/10. Diakses 6 Desember 2012)

Arbi Sanit. 2013 Rekrutmen Politik Pada Pemilu. (http://hitamandbiru. blogspot.com/2012/o7/rekrutmen-politik-pada-pemilu.html. Diakses 26 November 2013)

Budiman. 2013. Proses rekrutmen Politik (http://nasional.kompas.com/ $\mathrm{read} / 2013 / 09 / 05 / 1018475 /$ Proses. Rekrutmen. Politik. Neneknya.Korupsi diakses 26 November 2013)

Nelson Simanjuntak. 2013. Tindak Pelanggaran Kampanye (http://nasional.kompas.com/read/2013/11/25/2020043/Bawaslu.UU.Terbatas.Sulit. Tindak.Pelanggaran.Kampanye. Diakses 26 November 2013)

Ucok Sky Khadafi. DPR seharusnya diawasi tim independen (http://www.hukumonline.com/berita/baca/lt5008474701746/dpr-seharusnya-diawasitim -independen DPR Seharusnya Diawasi Tim Independen diakses 21 Agustus 2014) 
P-ISSN: 2684-9232, E-ISSN: 2685-1385 | 56

Anita Rachman, Hanya Empat Anggota DPR "Sempurna" (http://indo.wsj.com/posts/2014/04/21/hanya-empat-anggota-dpr-sempurna/ diakses 21 Agustus 2014)

Anonim. Badan kehormatan dpr, (http://badankehormatan.wordpress.com /category/badankehormatan-dprd/, diakses 24 Desember 2008). 